\title{
Studies on the transfer of calcium across the ovine placenta and incorporation into the foetal skeleton
}

\author{
By G. D. BRAITHWAITE, R. F. GLASCOCK AND \\ $\mathrm{SH}$. RIAZUDDIN \\ National Institute for Research in Dairying, Shinfield, Reading $R G 2{ }_{9} A T$ \\ (Received г6 fuly 1971-Accepted 4 October 1971)
}

\begin{abstract}
I. Radioactive calcium has been used to study the placental transfer of $\mathrm{Ca}$ in ewes at three stages of gestation.

2. At each stage virtually all the radioactive $\mathrm{Ca}$ injected into a foetus was still present $5-6 \mathrm{~h}$ later and little or none was found in the mother or in a twin foetus if present.

3. It was concluded that there is neither exchange of $\mathrm{Ca}$ between foetal and maternal pools nor transfer from foetus to mother. Passage of $\mathrm{Ca}$ across the placenta of the ewe is therefore a one-way process.

4. The rapidly exchangeable $\mathrm{Ca}$ pool of the foetus tended to increase in size with the stage of gestation and was found to contain only about half of the total Ca of the foetal soft tissues.

5. Two methods for calculating the rate of accretion of $\mathrm{Ca}$ into the foetal skeleton have been applied. The results obtained from these calculations suggested that rates of foetal bone accretion also increased with the stage of gestation. Accretion per unit foetal weight, however, remained fairly constant irrespective of age or number of foetuses present.

6. Bone accretion rates calculated from the tesults of the present work were very similar to the rates obtained previously for transfer of $\mathrm{Ca}$ across the sheep placenta, indicating that resorption of $\mathrm{Ca}$ from bone is negligible in the foetus.
\end{abstract}

The method of Aubert \& Milhaud (r960) for the quantitative measurement of the various processes of calcium metabolism in man gives satisfactory results in lactating ewes (Braithwaite, Glascock \& Riazuddin, I969). When the method is applied to pregnant ewes, however, the question arises as to whether foetal $\mathrm{Ca}$ is exchangeable with maternal serum $\mathrm{Ca}$ or whether it forms a separate non-exchangeable pool. Reports in the literature are conflicting, the behaviour of foetal $\mathrm{Ca}$ appearing to differ from species to species. Wasserman, Comar, Nold \& Lengemann (1957) and MacDonald, Hutchinson, Hepler \& Flynn (1965) reported a free movement of $\mathrm{Ca}$ ions in both directions across the placenta of the rat, rabbit and monkey. Symonds, Manston, Payne \& Sansom ( 1966 ), however, observed no back transfer in the goat of intrafoetally injected $\left[{ }^{32} \mathrm{P}\right]$ phosphate and they considered that $\mathrm{Ca}$ would behave in a similar manner. The present work was undertaken, therefore, to study the exchangeability of foetal $\mathrm{Ca}$ and the kinetics of its metabolism in the sheep.

\section{METHODS}

Animals. Six 4-year-old pregnant ewes, two Wensleydale-Teeswater crosses (Expts I and 2) and four Clun Forest (Expts $3-6$ ), were used and experiments were performed at $90-95, \mathbf{I} 20$ and $135^{-1} 4^{\circ} \mathrm{d}$ after conception. The number of foetuses present was determined by X-radiography, and one ewe carrying a single foetus and one carrying twins were selected for use at each of the three stages of gestation (see Table I). 
The animals were maintained on a diet of hay (unrestricted) and concentrates with added minerals and vitamins. The daily ration of concentrates consisted of the following mixture: $160 \mathrm{~g}$ barley, $80 \mathrm{~g}$ flaked maize, $40 \mathrm{~g}$ bran, $20 \mathrm{~g}$ linseed oil cake, $20 \mathrm{~g}$ mineral (Super Mindif; Boots Pure Drug Co., Nottingham) and $\mathrm{I} \cdot 4 \mathrm{~g}$ vitamin mixture (Drivite; Boots Pure Drug Co., Nottingham).

Experimental procedure. In Expts I, 3 and 4, performed under paravertebral anaesthesia, a uterine horn of each sheep was exposed through a flank incision and a known radioactivity $\left(20-40 \mu \mathrm{Ci}\right.$ ) of ${ }^{45} \mathrm{CaCl}_{2}$ (specific radioactivity $10 \mu \mathrm{Ci} / \mu \mathrm{g}$; Radiochemical Centre, Amersham, Bucks.) in aqueous solution was injected into a foetal placental vein. 'The wounds were sutured immediately after injection of the dose and the animals were allowed to recover. Expts 2, 5 and 6 were for the purpose of studying $\mathrm{Ca}$ kinetics in the foetus and were performed with the ewe under general anaesthesia (oxygen-cyclopropane). Anaesthesia was maintained for $2.5-3 \mathrm{~h}$ after injection of the dose, during which time frequent samples of foetal blood were withdrawn. These animals were then also allowed to recover.

Five to six $h$ after the injection (see Table $\mathrm{r}$ ) when most of the radioactivity had left the foetal blood, each of the six animals was killed and the uterus and contents were removed. The uterus, placenta and foetus were separated and the foetal fluid together with samples of maternal and foetal blood were collected. When twin foetuses were present, placental tissue and foetal fluid were collected from each separately. The foetal skeleton was dissected from the soft tissues and all samples, including the maternal carcass, were ashed at $600^{\circ}$. Each sample of ash was dissolved in a known volume of $2 \mathrm{M}-\mathrm{HCl}$. Blood samples were allowed to clot at room temperature, centrifuged for a few minutes at $2500 \mathrm{~g}$ and the serum was removed.

Determination of $\mathrm{Ca}$. Total $\mathrm{Ca}$ was measured by atomic absorption spectrophotometry by the methods of Willis (1960, 196r).

Measurement of radioactivity. Duplicate I $\mathrm{ml}$ samples of serum, foetal fluid and acid extracts of ashed tissues were added to $10 \mathrm{ml}$ portions of a scintillator solution of the following composition: $400 \mathrm{ml}$ anisole, $600 \mathrm{ml}$ methoxyethanol, I00 g naphthalene, $7.0 \mathrm{~g} \mathrm{2,5-diphenyloxazole} \mathrm{and} 0.3 \mathrm{~g}$ I,4-bis-(5-phenyloxazole-2-yl)benzene. Radioactivity was measured in a Tri-Carb liquid scintillation spectrometer (Packard model 33I4) and corrections for quenching and decay were made by the internal standard technique.

\section{RESULTS AND DISCUSSION}

As only one animal was used at each stage of pregnancy for either single or twin foetus, results must, of course, be interpreted with caution.

\section{Distribution of radioactive $\mathrm{Ca}$}

Table $x$ shows the recovery of radioactivity from foetal and maternal tissues after the injection of ${ }^{45} \mathrm{Ca}$ into foetuses at different stages of gestation. The recovery in all six experiments was $100 \pm 3 \%$ and at each stage of gestation virtually all the radioactivity remained in the injected foetus $(90.5-101 \cdot 9 \%)$. Only $0.2-0.4 \%$ was recovered from the twin foetus when present, and $0.5-6.9 \%$ from the mother. This small amount 
of radioactivity recovered from the mother was possibly the result of leakage at the site of the injection, especially in Expt I where the dose was administered with some difficulty. These results lead to the conclusion that there is neither exchange of $\mathrm{Ca}$ between foetal and maternal pools nor transfer from foetus to mother. Passage of Ca across the placenta of the ewe is therefore a one-way process as inferred by Symonds et al. (I966) for the goat. This contrasts with observations on other species. For example, it has been found that in the rabbit and monkey respectively $I \cdot 3-2 \cdot 1$ and $6-$ I o times as much $\mathrm{Ca}$ crosses the placenta as is incorporated into the foetus (Wasserman et al. I957; MacDonald et al. 1965).

Table I. Recovery and distribution (\% of dose) of radioactivity $5 \cdot 5^{-6} \mathrm{~h}$ after injection of ${ }^{45} \mathrm{CaCl}_{2}$ into a single foetus of ewes at different stages of gestation

\begin{tabular}{|c|c|c|c|c|c|c|c|c|c|c|c|}
\hline \multirow[b]{2}{*}{$\begin{array}{l}\text { Expt } \\
\text { no. }\end{array}$} & \multirow{2}{*}{$\begin{array}{l}\text { Stage } \\
\text { of } \\
\text { gesta- } \\
\text { tion } \\
\text { (d) }\end{array}$} & \multirow{2}{*}{$\begin{array}{c}\text { No. } \\
\text { of } \\
\text { foe- } \\
\text { tuses }\end{array}$} & \multirow{2}{*}{$\begin{array}{l}\text { Time } \\
\text { after } \\
\text { injec- } \\
\text { tion } \\
\text { (h) }\end{array}$} & \multicolumn{4}{|c|}{ Mother and foetus } & \multicolumn{4}{|c|}{ Injected foetus } \\
\hline & & & & $\begin{array}{l}\text { Injected } \\
\text { foctus }\end{array}$ & $\begin{array}{l}\text { Twin } \\
\text { foetus }\end{array}$ & Mother & $\begin{array}{l}\text { Total } \\
\text { recovery }\end{array}$ & Skeleton & $\begin{array}{c}\text { Soft } \\
\text { tissues }\end{array}$ & Placenta & $\begin{array}{l}\text { Foetal } \\
\text { fluid }\end{array}$ \\
\hline 3 & 90 & I & 6 & $96 \cdot 8$ & 一 & $3 \cdot I$ & $99^{\circ} 9$ & $68 \cdot 2$ & $12 \cdot 9$ & I $5 \cdot 1$ & 0.6 \\
\hline 4 & 95 & 2 & 6 & $99^{\circ} 9$ & 0.4 & $2 \cdot 5$ & $102 \cdot 8$ & $7^{8 \cdot 1}$ & 14.4 & 6.7 & 0.7 \\
\hline I & 120 & I & 6 & 90.5 & - & $6 \cdot 9$ & $97 \cdot 4$ & $74 \cdot I$ & $12 \cdot 4$ & $I \cdot 9$ & $2 \cdot I$ \\
\hline 5 & 120 & 2 & 6 & $95 \cdot 9$ & 0.2 & $1 \cdot 4$ & $97 \cdot 5$ & $78 \cdot 6$ & I $3 \cdot 7$ & $\mathbf{I} \cdot 8$ & $\mathrm{I} \cdot 8$ \\
\hline 2 & 135 & 2 & $5 \cdot 5$ & ror 9 & 0.2 & $\mathrm{I} \cdot 3$ & $\mathrm{IO} 3.4$ & $84 \cdot 6$ & I $3 \cdot 8$ & $\mathrm{I} \cdot 6$ & $I \cdot 9$ \\
\hline 6 & 140 & I & 6 & $99 \cdot 3$ & $\longrightarrow$ & 0.5 & $99 \cdot 8$ & $87^{\circ} 4$ & $8 \cdot 5$ & $2 \cdot 2$ & $1 \cdot 2$ \\
\hline
\end{tabular}

Table I also shows the distribution of radioactivity within the injected foetus. Within $6 \mathrm{~h}$ of injection about three-quarters of the total radioactivity in the foetus was located in the skeleton, showing that transfer of $\mathrm{Ca}$ to the foetal skeleton was very rapid. With older foetuses, less of the total radioactivity was present in the placenta than with younger ones. This may have been due to the fact that the ratio of placental to foetal soft tissues was smaller in older than in younger foetuses and hence the placenta contained a smaller proportion of the total $\mathrm{Ca}$ of the soft tissues.

In the five experiments in which determinations were made, the concentration of $\mathrm{Ca}$ in foetal serum was found to be appreciably higher than in maternal serum (Table 2). These results are in agreement with those of Needham (1931) and Bawdon, Wolkoff \& Flowers (1965) and support the theory of Comar (1956) that transfer of Ca across the placenta from mother to foetus is by a mechanism involving active transport rather than by diffusion.

\section{Kinetics of Ca metabolism}

In the pregnant ewe. Since the passage of $\mathrm{Ca}$ across the placenta of the ewe is a oneway process it must constitute an additional pathway by which $\mathrm{Ca}$ is lost from the rapidly exchangeable maternal pool P, as defined by Aubert \& Milhaud (Ig60). An extra term must therefore be added to their equation, expressing the relationships of the various processes of $\mathrm{Ca}$ metabolism, which may then be written

$$
V_{x^{r}}=V_{u}+V_{f}+V_{0+}+V_{y}
$$

where $V_{T}$ is the rate of irreversible flow of $\mathrm{Ca}$ from the rapidly exchangeable pool $\mathrm{P}, V_{u}$ is the rate of excretion of $\mathrm{Ca}$ in the urine, $V_{f}$ is the rate of excretion of $\mathrm{Ca}$ into 
the intestine (faecal endogenous $\mathrm{Ca}$ ),$V_{0+}$ is the rate of accretion of $\mathrm{Ca}$ into bone, and $V_{y}$ is the rate of transfer of Ca across the placenta.

Since the present work was done, this equation has been used for the calculation of rates of transfer across the placenta of the pregnant ewe (Braithwaite, Glascock \& Riazuddin, 1970).

Table 2. Concentration of calcium in maternal and foetal serum after injection of ${ }^{45} \mathrm{CaCl}_{2}$ into a single foetus of ewes at different stages of gestation

\begin{tabular}{|c|c|c|c|c|}
\hline \multirow[b]{2}{*}{$\begin{array}{c}\text { Fxpt } \\
\text { no. }\end{array}$} & \multirow[b]{2}{*}{$\begin{array}{l}\text { Stage of } \\
\text { gestation } \\
\text { (d) }\end{array}$} & \multicolumn{3}{|c|}{$\mathrm{Ca}$ concentration $(\mathrm{mg} / \mathrm{1} 00 \mathrm{ml})$} \\
\hline & & Mother & $\begin{array}{l}\text { Injected } \\
\text { foetus }\end{array}$ & $\begin{array}{l}\text { Twin } \\
\text { foetus }\end{array}$ \\
\hline 3 & 90 & $8 \cdot 7$ & I3. 8 & - \\
\hline 4 & 95 & 9.8 & $I^{1} x^{\circ} 9$ & $12: 3$ \\
\hline $\mathbf{I}$ & 120 & $9 \cdot 2$ & -- & - \\
\hline 5 & 120 & II.O & 134 & I 3.6 \\
\hline 2 & I35 & $7 \cdot 5$ & $10 \cdot 0$ & $x \times 6$ \\
\hline 6 & I 40 & $7 \cdot 2$ & $\mathrm{r} 2 \cdot 3$ & - \\
\hline
\end{tabular}

In the foetus. Ca metabolism in the foetus differs in many ways from that in the animal after birth. The gut and kidney play little or no part in it and foetal requirements for $\mathrm{Ca}$ are met by the passage of $\mathrm{Ca}$ across the placenta from the mother. Since none of this $\mathrm{Ca}$ returns to the mother, it must all be utilized by the foetus. Thus, whereas after birth the major pathways of gain and loss of $\mathrm{Ca}$ from the rapidly exchangeable $\mathrm{Ca}$ pool $\mathrm{P}$ can be represented by the equation

$$
V_{a}+V_{0-}=V_{0+}+V_{u}+V_{f}
$$

where $V_{a}$ is the rate of absorption of Ca from the intestine, $V_{0-}$ the rate of resorption of $\mathrm{Ca}$ from bone, and other symbols as before, a much simpler pattern of metabolism must operate in the foetus, i.e.

$$
V_{y}+V_{0-}=V_{0+}
$$

Calculation of the size of the rapidly exchangeable $C$ a pool $P$ of the foetus. At the end of all experiments, except the first, samples of foetal blood were taken. The specific radioactivity, $R_{s}$, of serum $\mathrm{Ca}$, which is identical to that of the $\mathrm{Ca}$ of pool $\mathrm{P}$ (Aubert \& Milhaud, I960), and the total radioactivity, $R_{x}$, in the soft tissues, were measured.

From the relationship

$$
\mathrm{P}=R_{x} \div R_{s}
$$

the size of $P$ in the foetus was calculated. Table 3 shows that $P$ tended to increase in size with the stage of gestation. Table 3 also gives the total $\mathrm{Ca}$ present in the foetal soft tissues at each of the stages of gestation, and it appears that $\mathrm{P}$ represented only about half this $\mathrm{Ca}$ and that this relationship was independent of foetal age or size.

Calculation of the rate of accretion of Ca into the foetal skeleton $\left(V_{0+}\right)$. In Expts 2, 5 and 6 , which were performed to study $\mathrm{Ca}$ kinetics in the foetus, serial samples of blood were taken up to $3 \mathrm{~h}$ after injection of the ${ }^{45} \mathrm{CaCl}_{2}$. These samples, together with blood collected at the end of the experiment $(5 \cdot 5-6 \mathrm{~h})$, allowed the curve of log specific radioactivity of foetal serum $\mathrm{Ca}$ against time to be plotted (Fig. I). Once the 
Ca was equilibrated within the rapidly exchangeable pool $\mathrm{P}$, the specific radioactivity of foetal serum $\mathrm{Ca}$ decreased mono-exponentially. Two methods of calculating the rate $\left(V_{0+}\right)$ of accretion of $\mathrm{Ca}$ into foetal bone were applied to the results obtained.

Method I depended on the specific radioactivity-time curve of foetal serum $\mathrm{Ca}$ and on the total radioactivity $\left(R_{z}\right)$ found in the foetal skeleton. Integration of the curve allowed the mean specific radioactivity $\left(\bar{R}_{\delta}\right)$ of foetal serum Ca over the experimental

\section{Table 3. Pool size and rate of accretion of calcium into bone of foetal sheep}

\begin{tabular}{|c|c|c|c|c|c|c|}
\hline Expt no. & 3 & 4 & I & 5 & 2 & 6 \\
\hline Stage of gestation (d) & 90 & 95 & 120 & 120 & I35 & 140 \\
\hline No. of foetuses & $\mathrm{I}$ & 2 & $\mathbf{I}$ & 2 & 2 & $\mathbf{r}$ \\
\hline $\begin{array}{l}\text { Slope of line of In specific radioactivity } v \text {. } \\
\text { time }(a)\end{array}$ & 4.89 & $6 \cdot I I$ & $6 \cdot 8 \mathrm{I}$ & $7 \cdot 02$ & $7 \cdot 74$ & $8 \cdot 48$ \\
\hline Rapidly exchangeable Ca pool (P) (ng) & 117 & 102 & 352 & 245 & 343 & 350 \\
\hline Total soft tissue $\mathrm{Ca}(\mathrm{mg})$ & 217 & $22 \mathrm{I}$ & 738 & 520 & 817 & 706 \\
\hline Pool $\mathrm{P}$ as $\%$ of total $\mathrm{Ca}$ in soft tissues* & $53 \cdot 8$ & $46 \cdot I$ & $47 \cdot 7$ & $47 \cdot 1$ & $42 \cdot 0$ & $49^{\cdot 6}$ \\
\hline \multicolumn{7}{|c|}{ Method I for calculation of $V_{0+}$} \\
\hline \multicolumn{4}{|c|}{$\begin{array}{l}\text { Rate of loss of Ca from } \mathbf{P}\left(V_{\mathrm{T}}\right)(\mathrm{mg} / \mathrm{d})\left(V_{\mathrm{T}}=V_{0,+}+V_{\mathrm{S}}\right) \\
\text { Rate of accretion of Ca into bone }\left(V_{0+}\right)\end{array}$} & 1632 & 2604 & 2700 \\
\hline \multirow{2}{*}{\multicolumn{4}{|c|}{$\begin{array}{l}\mathrm{mg} / \mathrm{d} \\
\mathrm{mg} / \mathrm{d} \mathrm{kg} \text { foetal body-wt }\end{array}$}} & 930 & I 484 & I 539 \\
\hline & & & & 465 & 489 & $45^{2}$ \\
\hline \multicolumn{7}{|c|}{ Method 2 for calculation of $V_{0+}$} \\
\hline $\begin{array}{l}\text { Rate of loss of Ca from } \mathrm{P}\left(V_{\mathrm{T}}\right)(\mathrm{mg} / \mathrm{d}) \\
\left(V_{\mathrm{T}}=V_{\mathrm{a}+}+V_{\mathrm{E}}\right)\end{array}$ & 570 & 620 & 2397 & 1720 & 2650 & 2967 \\
\hline \multicolumn{7}{|l|}{ Rate of accretion of $\mathrm{Ca}$ into bone $\left(V_{\mathrm{a}+}\right)$} \\
\hline $\mathrm{mg} / \mathrm{d}$ & 320 & 350 & I366 & 980 & I 5 IO & $169 \mathrm{I}$ \\
\hline $\mathrm{mg} / \mathrm{d} \mathrm{kg}$ foetal body-wt & 540 & 518 & 455 & 500 & 498 & 497 \\
\hline $\begin{array}{l}\text { Rate of exchange of serum } \mathrm{Ca} \text { with the } \\
\text { slowly exchangeable } \mathrm{Ca} \text { of bone }\left(V_{\mathrm{A}}\right)\end{array}$ & 250 & 270 & 1031 & 740 & I I 40 & 1276 \\
\hline
\end{tabular}

a of bone $\left(V_{\text {B }}\right)$

* The mean value of this quantity for Expts 2-6 (47.7\%) was used to calculate the size of the rapidly exchangeable Ca pool ( $352 \mathrm{mg})$ in Expt $\mathrm{I}$, in which a serum sample was not obtained.

period $(t)$ to be calculated. The total radioactivity incorporated into foetal bone during the experimental period was the result of two processes, accretion and slow exchange, whose rates were $V_{0+}$ and $V_{z i}$ respectively. Their sum was calculated from the relationship

$$
V_{0+}+V_{E}=R_{z} \div\left(\bar{R}_{s} \times t\right) \text {. }
$$

In the present work, as already noted, the specific radioactivity-time curve of foetal serum $\mathrm{Ca}$ was obtained only in three experiments performed during the later stages of gestation, and application of this method of calculation gave values for $V_{0+}+V_{E}$ shown in Table 3 .

It has been observed that the ratio $V_{0+} \div\left(V_{0+}+V_{E}\right)$ has a value of $0.54-0.60$ in sheep between the ages of 2 months and 2 years (unpublished results). It would therefore seem reasonable to apply this same ratio (mean value 0.57 ) to the calculation of $V_{0+}$ in the foetus, i.e.

$$
V_{0+}=0.57\left(V_{0+}+V_{E}\right)
$$

and the resulting values of $V_{0+}$ are shown in Table 3 .

Method 2 required the slope of the linear portion of the curve of $\ln$ specific 
radioactivity against time for foetal serum $\mathrm{Ca}$. This curve was obtained only in Expts 2, 5 and 6 . However, its slope could be found indirectly from the total radioactivity injected and the total radioactivity found in soft tissues at the end of the experiment. Thus, the dose of radioactive $\mathrm{Ca}$ injected was taken to represent the total radioactivity that the soft tissues would have contained at zero time if mixing had been instantaneous. This value and the total radioactivity actually found in soft tissues at the end of the experiment were plotted on semi-logarithmic

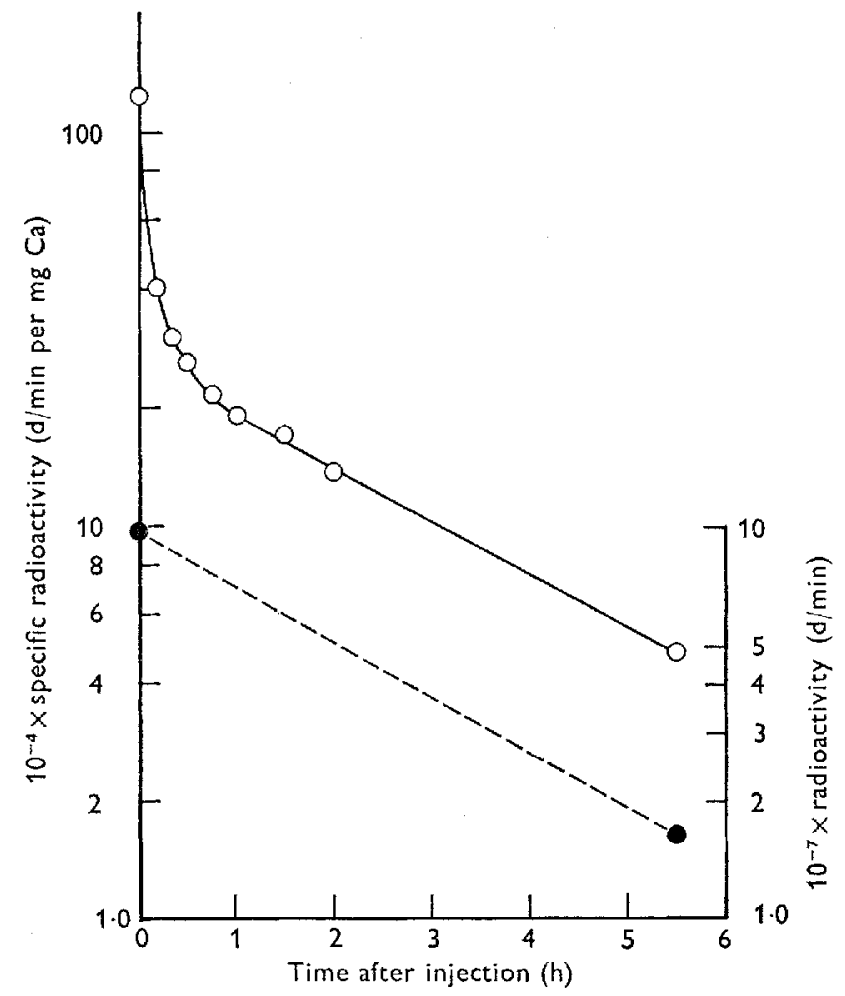

Fig. I. Expt 2. Ovine foetus injected with ${ }^{45} \mathrm{CaCl}_{2}$. Graph showing variations in specific radioactivity with time of $(O)$ foetal serum $\mathrm{Ca}$ and $(O)$ total radioactivity in foetal soft tissues (logarithmic ordinates: left side for specific radioactivity of serum $\mathrm{Ca}$; right side for total radioactivity in foetal soft tissues).

co-ordinates. The straight line connecting the points was then found to have the same slope as the linear portion of the specific radioactivity-time curve of serum Ca (Fig. I). Aubert \& Milhaud (1960) have shown that when the specific radioactivity of serum $\mathrm{Ca}$ is decreasing as a single exponential, i.e. when

then

$$
R_{s}=A e^{-a t}
$$

$$
V_{T}=a \mathrm{P},
$$

where $A$ is the specific radioactivity of serum Ca at zero time and $a$ is the slope of the linear portion of the curve of $\ln$ specific radioactivity against time for serum $\mathrm{Ca}$. 
As the present work has shown that virtually no Ca leaves the foetus as a whole, all $\mathrm{Ca}$ leaving the foetal pool $\mathrm{P}$ must enter bone, i.e.

$$
V_{T}=V_{0+}+V_{E}
$$

It follows from equations (6) and (7) that in the foetus

$$
V_{0+}+V_{E}=a \mathrm{P} \text {. }
$$

Values for $V_{0+}+V_{E}$ can therefore be calculated and the corresponding values for $V_{0+}$ can be obtained by application of the factor of 0.57 used previously.

Bone accretion rates were calculated for all six sheep by the second method described above. The values obtained, however, were greater than those obtained by the first method, because transfer of $\mathrm{Ca}$ of high specific radioactivity to the foetal skeleton during the ist hour after the injection is not taken into account when only the linear portion of the curve of In specific radioactivity against time is used. It must be emphasized that this method is not critical and tends to overestimate $V_{0+}$. It is still useful, however, for the purposes of comparison and has been so used by other workers on adult animals (Aubert \& Milhaud, I960; Young, Luick \& Lofgreen, 1966). In the present work (Table 3 ) bone accretion rates were four to five times as great at I $20-140 \mathrm{~d}$ of gestation as at $90-95 \mathrm{~d}$. Furthermore, at the later stages, values were lower in twin than in single foetuses. When the accretion rate per unit foctal weight was calculated, however, it was found to be fairly constant, irrespective of age or number of foetuses present. Braithwaite et al. (1970) found that the rate of passage of $\mathrm{Ca}$ across the ewe placenta $\left(V_{y}\right)$ when corrected to unit foetal body-weight was also nearly constant in the later stages of gestation. Since $V_{y}=V_{0+}-V_{0-}$ (equation 3) the value of $V_{0+}$ would be expected to be greater than that of $V_{y}$ unless bone resorption $\left(V_{0-}\right)$ were negligible. In fact, the values for $V_{0+}$ calculated by method 2 (455$540 \mathrm{mg} / \mathrm{d} \mathrm{kg}$ foetal body-weight) were greater than those previously found for $V_{y}$ $(360-49 \circ \mathrm{mg} / \mathrm{d} \mathrm{kg}$ foetal body-weight), but as explained above, this method overestimates $V_{0+}$ and the more accurate values obtained by method I $\left(45^{2-489} \mathrm{mg} / \mathrm{d} \mathrm{kg}\right.$ foetal body-weight) are very similar to those for $V_{y}$. These results indicate, therefore, that bone resorption $\left(V_{0-}\right)$ in the ovine foetus is negligible. Hence, in the foetus, $V_{y}=V_{0+}$.

This result contrasts with that obtained in young growing sheep where bone accretion remained fairly constant and bone resorption was responsible for Ca homoeostasis (Braithwaite \& Raizuddin, 1971).

We acknowledge with thanks the skilled surgery of Dr H. L. Buttle and Dr A. T. Cowie. We also thank Mr G. Lovering for technical assistance and Messrs R. C. Ellis and A. Wilim for looking after the animals. One of us (Sh. Riazuddin, a visiting worker from the Pakistan Atomic Energy Commission, Lahore) was the holder of a Colombo Plan Fellowship. 


\section{REFERENCES}

Aubert, J.-P. \& Milhaud, G. (1960). Biochim. biophys. Acta 39, 122.

Bawden, J. W., Wolkoff, A. S. \& Flowers, C. E. (1965). Obstet. Gynec. $25,548$.

Braithwaite, G. D., Glascock, R. F. \& Riazuddin, Sh. (1969). Br. F. Nutr. 23, 827.

Braithwaite, G. D., Glascock, R. F. \& Riazuddin, Sh. (I970). Br. F. Nutr. 24, 66r.

Braithwaite, G. D. \& Riazuddin, Sh. (1971). Br. F. Nutr. 26, 2 I 5 .

Comar, C. L. (1956). Ann. N.Y. Acad. Sci. 64, 281.

MacDonald, N. S., Hutchinson, D. L., Hepler, M. \& Flynn, E. (1965). Proc. Soc, exp. Biol. Med. II9, 476 .

Needham, J. (1931). Chemical Embryology. London: Cambridge University Press.

Symonds, H. W., Manston, R., Payne, J. M. \& Sansom, B. F. (1966). Br. vet. F. 122, 196.

Wasserman, R. H., Comar, C. L., Nold, M. M. \& Lengemann, F. W. (1957). Am. F. Physiol. r89, 9 r.

Willis, J. B. (1960). Spectrochim. Acta r6, 259.

Willis, J. B. (1961). Analyt. Chem. 33, 556.

Young, V. R., Luick, J. R. \& Lofgreen, G. P. (1966). Br. F. Nutr. 20, 727. 